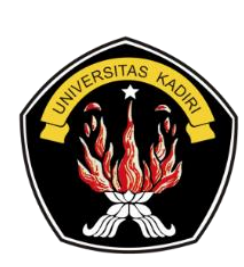

Tersedia secara online di http://ojs.unik-kediri.ac.id/index.php/jatiunik/issue/view/76

\title{
Analisis Bahaya Covid-19 Untuk Upaya Pencegahan Penyebaran Pada Fasilitas Umum Taman Kota Dengan Menerapkan Metode Hazard Identification, Risk Assessment And Risk Control (HIRARC)
}

\author{
Alwan Taufiqurrohman ${ }^{* 1}$, Firdy Ganjar $\mathbf{N}^{2}$, Frans Hill ${ }^{3}$, Irvan Apriadi $\mathbf{M}^{4}$, Devi Hadi $\mathbf{P}^{5}$, \\ Salafudin 6 \\ 1,2,3,4,5,6Program Studi Teknik Kimia, Institut Teknologi Nasional, Bandung \\ Email : obred1412@gmail.com
}

Informasi Artikel
Riwayat Artikel :
Received : $25-$ Juli - 2020
Revised : $10-$ Oktober -2020
Accepted : 16 - Oktober - 2020

Kata kunci :

City park

Covid-19

Sport

Virus

\begin{abstract}
Corona virus or what can be called Covid-19 has become a pandemic throughout the world, many activities such as teaching and learning, work, and even sports were suspended because of the Covid-19. Covid-19 can spread very quickly because this virus makes use of various types of crowds and can cause death. With the termination of various kinds of activities that involve physical contact and human encounters can reduce the spread of the Covid-19 virus significantly. The virus that can develop for 14 days on its host body is very dangerous so that Social Distancing and even Physical Distancing activities are carried out to reduce the spread of Covid-19. With the implementation of Physical Distancing for 14 days, humans who are infected without symptoms can get out of the house but with a health protocol by wearing a mask, not close to each other, and always washing hands. By maintaining health as well as sports, the development of this virus in the body can slow down. Usually sports are carried out in city parks, health protocols and facilities that can help reduce the spread of the Covid-19 virus can be done in city parks.
\end{abstract}

Untuk melakukan sitasi pada penelitian ini dengan format : D. K. Chu et al., "Physical distancing, face masks, and eye protection to prevent person-toperson transmission of SARSCoV-2 and COVID-19: a systematic review and metaanalysis," Lancet, vol. 395, no. 10242, pp. 1973-1987, Jun. 2020.

\begin{abstract}
A b s t rak
Virus Corona atau yang bisa disebut dengan Covid-19 sudah menjadi pandemi di seluruh dunia, banyak kegiatan seperti belajar mengajar, bekerja, bahkan olahraga diberhentikan sementara karena adanya Covid-19 ini. Covid-19 yang dapat menyebar dengan sangat cepat karena virus ini memanfaatkan berbagai jenis keramaian dan dapat menyebabkan kematian. Dengan diberhentikannya berbagai macam kegiatan yang melibatkan kontak fisik dan pertemuan antar manusia dapat membuat penyebaran virus Covid-19 berkurang dengan signifikan. Virus yang dapat berkembang selama 14 hari pada tubuh inangnya ini sangat berbahaya sehingga kegiatan Social Distancing bahkan Physical Distancing dilakukan untuk mengurangi angka penyebaran Covid-19 ini. Dengan diberlakukannya Physical Distancing selama 14 hari, manusia
\end{abstract}


yang tertular tanpa gejala sudah dapat keluar dari rumah tetapi dengan protokol kesehatan dengan cara memakai masker, tidak berdekatan satu sama lain, dan selalu cuci tangan. Dengan menjaga kesehatan pula seperti olahraga, perkembangan virus ini pada tubuh dapat melambat. Biasanya olahraga dilakukan di taman kota, protokol kesehatan dan fasilitas yang dapat membantu mengurangi penyebaran virus Covid-19 ini dapat dilakukan pada taman kota.

\section{Pendahuluan}

Perkembangan virus covid-19 yang sedang melanda negara Indonesia bahkan dunia menyebabkan segala kegiatan terhambat[1]. Dalam hal ini, sebagian masyarakat harus berada dirumah untuk melakukan anjuran pemerintah, selain itu banyak dikerahkan tenaga medis untuk melakukan pengecekan diarea - area yang sudah di sesuaikan untuk dikawal dan melakukan tes suhu sebagai langkah awal penanganan covid - 19 [2]. Virus tersebut memiliki dampak yang berbahaya bagi manusia, selain itu jika setiap orang tidak mematuhi protokol kesehatan yang dianjurkan akan menerima dampaknya [3]. Sebagian orang mengawali hari pada saat hari libur kerja untuk berpergian ke tempat yang sejuk serta bisa melakukan berbagai kegiatan salah satunya taman, disini banyak hal yang bisa mereka lakukan diantaranya ada yang berolahraga, wisata kuliner, jalan-jalan santai, mencari sarapan, mencari udara segar, dan lain sebagainya. Tempat ini tentunya sangat ramai banyak orang yang berdatangan dari berbagai penjuru kota untuk melakukan aktifitas mereka disini, dikhawatirkan dengan banyaknya orang berkumpul disini bisa menyebabkan penularan virus semakin cepat dapat dilihat dari jarak antar orang perorang sangat minim ditambah banyak yang tidak sesuai protokol kesehatan, banyak orang yang menyepelekan hal kecil seperti memakai masker yang sangat dianjurkan pada saat beraktifitas diluar rumah yang tidak mereka indahkan, maka dari itu kami berinisiatif membuat suatu rancangan tentang bahaya, penanggulangannya serta SOP yang sesuai supaya menjadi perhatian untuk semua orang yang sedang berada ditempat tersebut [4]. Dengan adanya rancangan ini diharapkan dapat menekan penyebaran virus tetapi tidak menghambat aktifitas seperti biasa.

Penelitian ini bertujuan untuk mengetahui kegiatan yang memiliki risiko sedang, risiko tinggi dan risiko ekstrem pada area taman kota terhadap paparan covid-19. Metode yang digunakan adalah Hazard Identification, Risk Assessment And Risk Control [5]. Penelitian ini, lebih mencangkup pada risiko yang disebabkan oleh virus covid-19 yang ditinjau menggunakan metode HIRARC. Metode tersebut banyak digunakan di kalangan industri untuk melakukan analisis terhadap risisko -risiko yang ditimbulkan akibat pekerjaan yang memiliki orientasi berbahaya dan memiliki risiko mulai tingkat rendah sampai tinggi. Dalam hal ini, jika metode tersebut dikaitkan dengan dampak covid-19, setiap orang diharuskan untuk sering melakukan cuci tangan ketika setelah melakukan aktivitas baik kontak langsung dengan lawan bicara, maupun fasilitas yang digunakan secara umum. Tindakan tersebut adalah salah satu pengendalian minimalisir virus covid-19, serta diperlukan sosialisasi guna menyadarkan masyarakat yang kurang memahami akan dampak dari virus tersebut. Metode HIRARC ini digunakan untuk melakukan identifikasi kegiatan masyarakat dan dihasilkan pengendalian risiko untuk meminimalisir paparan virus tersebut [6]. 


\section{Tinjauan Pustaka}

\subsection{Covid-19}

Covid-19 adalah nama penyakit yang disebabkan virus corona dan secara resmi disahkan oleh WHO (World Health Organzation). Covid adalah singkatan dari Corona Virus Disease-2019. Covid-19 disebabkan oleh virus corona menyerang saluran pernafasan yang menyebabkan demam, flu, tinggi, batuk sesak nafas dan nyeri tenggorokan [3]. Virus corona adalah keluarga besar virus yang menyebabkan penyakit pada hewan maupun manusia. Penyakit yang timbul dari covid-19, yang lebih parah seperti Middle East Respiratory Syndrome (MERS), dan Severe Acute Respiratory Syndrme (SARS). Virus ini mengakibatkan orang kehilangan nyawa sehingga WHO telah menjadikan status virus corona ini menjadi pandemi [7].

\subsection{HIRARC}

Suatu risiko akan individu hadapai sehari-hari. Secara umum yaitu masyarakat pada untuk membuat keputusan berdasarkan risiko yang ada. Dalam hal ini, pilihan sederhana antara lain kegiatan disekolah, kegiatan liburan dan lainnya [8]. Risiko adalah kombinasi dari likelihood (kemungkinan) pada kejadian yang berbahaya yang mungkin terjadi dengan waktu tertentu. Severity adalah hasil dari kejadian pada tingkat keparahan kesehatan seseorang, atau kerusakan fasilitas disebabkan peristiwa. Risiko adalah peluang terjadinya dampak terhadap sasaran, yang diukur dengan hukum sebab akibat. Risiko diukur berdasarkan nilai probability dan consequences [9]. Konsekuensi atau dampak hanya akan terjadi bila ada bahaya dan kontak atau exposure antara manusia dengan peralatan ataupun material yang terlibat dalam suatu interaksi [10], [11].

Tabel 1. Tingkat Ketidakpastian

\begin{tabular}{lll}
\hline Tingkat Ketidakpastian & \multicolumn{1}{c}{ Karakteristik } & \multicolumn{1}{c}{ Contoh } \\
\hline Tidak ada (pasti) & $\begin{array}{l}\text { Hasil bisa diprediksi } \\
\text { dengan pasti }\end{array}$ & Hukum alam \\
\hline Ketidakpastian objektif & $\begin{array}{l}\text { Hasil bisa diidentifikasi dan } \\
\text { probabilitas diketahui }\end{array}$ & Permainan dadu, kartu \\
\hline Ketidakpastian & $\begin{array}{l}\text { Hasil bisa diidentifikasi } \\
\text { subjektif }\end{array}$ & $\begin{array}{l}\text { Kebakaran, kecelakaan, } \\
\text { mobil, investasi }\end{array}$ \\
\hline Sangat tidak pasti & $\begin{array}{l}\text { Hasil tidak bisa } \\
\text { diidentifikasi dan }\end{array}$ & Eksplorasi angkasa \\
& probabilitas tidak diketahui & \\
\hline
\end{tabular}

(Sumber : [12]

Tingkat ketidakpastian meninjau dari karakteristik dan adanya contoh ketidakpastian. Setiap risiko memiliki pengelompokan sebagai berikut :

1. Risiko murni (pure risks) yaitu risiko yang menimbulkan kerugian tetapi masih memiliki nilai keuntungan [12].

2. Risiko spekulatif adalah risiko berpotensi mengharapkan terjadinya kerugian dan juga keuntungan. Menurut [12] potensi kerugian dan keuntungan akan berkaitan dengan laba jika ditinjay dari bisnis.. 
Tabel 2. Frekuensi Kejadian

\begin{tabular}{cccc}
\hline Level & Deskripsi & Keterangan & Frekuensi \\
\hline 5 & Hampir pasti & $\begin{array}{c}\text { Kejadian diharapkan } \\
\text { muncul diberbagai situasi }\end{array}$ & $>1$ kali setahun \\
\hline 4 & Sering & $\begin{array}{c}\text { Kejadian mungkin muncul } \\
\text { diberbagai situasi }\end{array}$ & $\geq 1$ kali setahun \\
\hline 3 & Moderat & $\begin{array}{c}\text { Kejadian seharusnya } \\
\text { muncul disaat yang sama }\end{array}$ & $\geq 1$ kali 5 tahun \\
\hline 1 & Jarang & $\begin{array}{c}\text { Kejadian dapat muncul } \\
\text { disaat yang sama }\end{array}$ & $<1$ tahun \\
\hline
\end{tabular}

(Sumber : [12]

Tingkat frekuensi tersebut digunakan sebagai asumsi, seberapa sering terjadi dampak yang ditimbulkan dari masalah tersebut. Selain itu, jika dampak yang timbul semakin sering, akan memiliki potensi besar jika terjadi berulang kali. Oleh sebab itu diberikan deskripsi mulai dari sangat jarang terjadi sampai dengan hampir pasti terjadi dengan keterangan mulai dari kejadian yang muncul pada keadaan tertentu sampai dengan kejadian yang diharapkan dapat muncul diberbagai situasi dan memiliki potensi besar setiap kali timbul masalah tersebut. Lebih dari itu, dimunculkan matriks dampak yang timbul dari kegiatan yang diindentifikasi bahayanya, sebagai berikut :

Tabel 3. Dampak Akibat Yang D Timbulkan

\begin{tabular}{|c|c|c|c|c|c|c|c|}
\hline \multicolumn{8}{|c|}{ Dampak } \\
\hline \multirow[b]{2}{*}{ Signifikan } & & & 1 & 2 & 3 & 4 & 5 \\
\hline & & & $\begin{array}{l}\text { Insignifikan } \\
\text { impact }\end{array}$ & $\begin{array}{l}\text { minor } \\
\text { impact }\end{array}$ & $\begin{array}{l}\text { moderate } \\
\text { mino }\end{array}$ & $\begin{array}{l}\text { major } \\
\text { impact }\end{array}$ & $\begin{array}{l}\text { major } \\
\text { impact to } \\
\text { large }\end{array}$ \\
\hline \multirow{5}{*}{$\begin{array}{c}\text { Kemungkinan } \\
\text { kejadian }\end{array}$} & 5 & $\begin{array}{l}\text { Almost } \\
\text { certain }\end{array}$ & Low & Moderate & High & Extreme & Extreme \\
\hline & 4 & likely & Low & Moderate & Moderate & High & Extreme \\
\hline & 3 & moderate & Very low & Low & Moderate & High & High \\
\hline & 2 & unlikely & Very low & Very low & Low & Moderate & High \\
\hline & 1 & rare & Very low & Very low & Low & Moderate & Moderate \\
\hline
\end{tabular}

Sumber : [13]

Tabel 4. Respon Risiko

\begin{tabular}{cl}
\hline Level risiko & \multicolumn{1}{c}{ Kriteria } \\
\hline $1-3$ & Pengendalian dapat diterima/ cukup \\
\hline $4-6$ & Pengendalian dapat dipantau \\
\hline $6-9$ & Pengendalian mampu di manajemen \\
\hline $10-14$ & Pengendalian harus diperhatikan \\
\hline $15-25$ & Pengendalian tidak dapat diterima
\end{tabular}

Sumber : [13] 


\section{Metode Penelitian}

Metode penelitian yang digunakan adalah dengan penelitian deskriptif dengan lama penelitian sejak bulan April 2020 sampai dengan Mei 2020. Hasil penelitian ini merupakan hasil dari riset data berdasarkan pengumpulan data dan jurnal-jurnal penelitian, pengkajian data dan jurnal-jurnal penelitian secara online [14], [15]. Penelitian ini bertujuan untuk memberi informasi risiko dari kegiatan yang dilakukan dan berbagai konsekuensinya sehingga sebisa mungkin untuk mengikuti protokol kesehatan untuk mengurangi penularan virus. Nilai dari risiko dan seberapa mungkin tertular virus karena kegiatan yang dilakukan akan diperlihatkan dalam tingkat likelihood dan severity. Objek penelitian yang diambil merupakan kegiatan di taman kota yang berpotensi dan mempunyai risiko untuk menularkan virus Covid-19. Teknik analisis data yang digunakan sebagai berikut :

a. Melakukan observasi pada taman untuk mengetahui kegiatan apa saja yang dilakukan oleh pengunjung dalam kurun waktu penelitian [16].

b. Melakukan identifikasi bahaya, risiko dan akibat yang ditimbulkan dari kegiatan tersebut [17], [18], [19].

c. Melakukan risk assessment matrix dengan cara mengalikan nilai likelyhood dan severity untuk menghasilkan nilai Likelyhood Severity [20], [21].

d. Rentang nilai yang digunakan pada penilaian likelyhood dan severity adalah 1 sampai dengan 10 [22], [23].

e. Setelah diketahui nilai perkalian dari Likelyhood dan Severity, dilakukan pengendalian risiko secara subyektif [24], [25], [26].

f. Setelah itu, dilakukan analisis hasil dari penilaian tersebut, untuk memperjelas hasil penelitian secara terurai, ringkas dan jelas.

g. Dilakukan penyimpulan dan pemberian saran dari penelitian tersebut.

h. Selesai.

\section{Hasil dan Pembahasan}

Dari berbagai macam kegiatan yang dilakukan di taman, ada beberapa bahaya yang dapat terjadi dan menularkan virus Covid-19. Pada penelitian ini, ada 8 kegiatan dengan potensi bahaya yang berperan dalam penularan virus Covid-19, kegiatan yang dilakukan mempunyai nilai risiko yang berbeda-beda bergantung pada seberapa sering dan terjadinya kegiatan yang dilakukan tersebut. Nilai dari risiko ini dapat dilihat pada tabel Hazard Identification and Risk Assessment (HIRARC) [27], kemudian pengendalian risiko untuk mengendalikan risiko dan meminimalisir penularan yang terjadi pada tabel Risk Control:

Tabel 5.Penilaian Risk Assessment Matrix

\begin{tabular}{|c|c|c|c|c|c|}
\hline \multirow[t]{2}{*}{ No. } & \multirow[t]{2}{*}{ Aktivitas } & \multirow[t]{2}{*}{ Bahaya } & \multirow[t]{2}{*}{ Risiko } & \multirow[t]{2}{*}{ Akibat } & $\begin{array}{c}\text { Risk Assessment } \\
\text { Matrix }\end{array}$ \\
\hline & & & & & LR \\
\hline
\end{tabular}




\begin{tabular}{|c|c|c|c|c|c|c|c|}
\hline 1 & Berjualan & $\begin{array}{l}\text { Kontak } \\
\text { langsnung } \\
\text { dengan pembeli } \\
\text { karena perantara } \\
\text { jual beli }\end{array}$ & $\begin{array}{l}\text { Tertular virus } \\
\text { baik pembeli } \\
\text { maupu } \\
\text { penjual }\end{array}$ & $\begin{array}{l}\text { Virus menyebar } \\
\text { disekitar } \\
\text { lingkungan } \\
\text { tersebut }\end{array}$ & 2 & 2 & 5 \\
\hline 2 & $\begin{array}{l}\text { Berfoto } \\
\text { dengan } \\
\text { rekan }\end{array}$ & $\begin{array}{l}\text { Jika salah satu } \\
\text { tertular melalui } \\
\text { sentuhan, } \\
\text { lainnya juga ikut } \\
\text { tertular virus }\end{array}$ & $\begin{array}{l}\text { Akan tertular } \\
\text { virus }\end{array}$ & $\begin{array}{l}\text { Orang yang } \\
\text { berfoto akan } \\
\text { ikut tertular satu } \\
\text { sama lain }\end{array}$ & 4 & 3 & 12 \\
\hline 3 & $\begin{array}{l}\text { Berkumpul } \\
\text { dan } \\
\text { nongkrong } \\
\text { dengan } \\
\text { teman }\end{array}$ & $\begin{array}{l}\text { Jika salah satu } \\
\text { tertular, lingkup } \\
\text { tersebut juga } \\
\text { akan ikut tertular }\end{array}$ & $\begin{array}{l}\text { Dapat tertular } \\
\text { virus }\end{array}$ & $\begin{array}{lr}\text { Virus akan } \\
\text { menyebar ke } \\
\text { lingkungan dan } \\
\text { orang } \\
\text { nongkrong jika } \\
\text { terjadi kontak } \\
\text { langsung atau } \\
\text { droplet }\end{array}$ & 4 & 4 & 16 \\
\hline 4 & $\begin{array}{l}\text { Duduk di } \\
\text { kursi taman }\end{array}$ & $\begin{array}{l}\text { Virus bisa saja } \\
\text { menempel pada } \\
\text { kursi taman }\end{array}$ & $\begin{array}{l}\text { Virus yang } \\
\text { menempel } \\
\text { akan ikut } \\
\text { terbawa pada } \\
\text { orang yang } \\
\text { duduk dikursi } \\
\text { tersebut }\end{array}$ & $\begin{array}{l}\text { Akan tertular } \\
\text { virus }\end{array}$ & 2 & 2 & 4 \\
\hline 5 & Olahraga & $\begin{array}{l}\text { Jika terjadi suhu } \\
\text { tinggi saat } \\
\text { olahraga, dapat } \\
\text { menimbulkan } \\
\text { gejala }\end{array}$ & $\begin{array}{l}\text { Akan mudah } \\
\text { terkena virus, } \\
\text { jika suhu } \\
\text { tinggi }\end{array}$ & $\begin{array}{l}\text { Mudah tertular, } \\
\text { jika terjadi } \\
\text { kontak langsung } \\
\text { maupun lewat } \\
\text { udara }\end{array}$ & 2 & 3 & 6 \\
\hline 6 & $\begin{array}{l}\text { Petugas } \\
\text { kebersihan } \\
\text { membersihk } \\
\text { an taman }\end{array}$ & $\begin{array}{l}\text { Kontak langsung } \\
\text { dengan sampah } \\
\text { di area taman }\end{array}$ & $\begin{array}{l}\text { Jika benda } \\
\text { yang } \\
\text { dipegang ada } \\
\text { virusnya, } \\
\text { akan terjadi } \\
\text { penularan }\end{array}$ & $\begin{array}{l}\text { Akan terjangkit } \\
\text { virus }\end{array}$ & 2 & 2 & 4 \\
\hline 7 & $\begin{array}{l}\text { Penggunaan } \\
\text { toilet taman }\end{array}$ & $\begin{array}{l}\text { Jika memegang } \\
\text { gagang pintu, } \\
\text { wastafel yang } \\
\text { terkontaminasi } \\
\text { virus }\end{array}$ & $\begin{array}{l}\text { Tertular } \\
\text { karena terjadi } \\
\text { kontak pada } \\
\text { benda di toilet }\end{array}$ & $\begin{array}{l}\text { Pengguna dapat } \\
\text { tertular }\end{array}$ & 3 & 2 & 6 \\
\hline
\end{tabular}




\begin{tabular}{llllllll}
\hline 8 & Penggunaan & Menyentuh kran & Tertular jika Pengguna & 3 & 2 & 6 \\
mushola & wudhu, kamar menggunaka tertular virus & & & \\
taman & mandi, dan n fasilitas & & & \\
& lantai untuk mushola & & \\
& ibadah tanpa tanpa kehati- & & \\
& ada sterilisasi hatian & & \\
& terlebih dahulu & & & \\
&
\end{tabular}

Tabel 6. Pengendalian Risiko

\begin{tabular}{|c|c|c|c|}
\hline No. & Aktivitas & Risiko & Pengendalian Risiko \\
\hline 1 & Berjualan & Terinfeksi Covid - 19 & $\begin{array}{l}\text { Berjualan saat kondisi sehat, } \\
\text { menyediakan handsanitizer dan } \\
\text { menggunakan masker serta jaga } \\
\text { jarak antar pembeli minimal } 3 \\
\text { meter }\end{array}$ \\
\hline 2 & $\begin{array}{l}\text { Berfoto dengan } \\
\text { rekan }\end{array}$ & Terinfeksi Covid - 19 & $\begin{array}{l}\text { Pastikan tidak berasal dari luar } \\
\text { kota yang zona merah covid- } \\
\text { 19, serta jaga jarak dan membawa } \\
\text { handsanitizer serta menggunakan } \\
\text { masker }\end{array}$ \\
\hline 3 & $\begin{array}{l}\text { Berkumpul dan } \\
\text { nongkrong dengan } \\
\text { teman }\end{array}$ & Terinfeksi Covid - 19 & $\begin{array}{l}\text { Menjaga jaraksatu sama lain, } \\
\text { menggunakan masker dan } \\
\text { membawa handsanitizer dan tidak } \\
\text { melakukan kontak secara langsung } \\
\text { tanpa masker. }\end{array}$ \\
\hline 4 & $\begin{array}{l}\text { Duduk di } \quad \text { kursi } \\
\text { taman }\end{array}$ & Terinfeksi Covid - 19 & $\begin{array}{l}\text { Menjaga jarak saat duduk dan } \\
\text { memastikan kondisi tempat duduk } \\
\text { sudah di bersihkan dan diberikan } \\
\text { antiseptik, kemudian ganti baju } \\
\text { ketika sudah sampai rumah dan } \\
\text { mencucinya }\end{array}$ \\
\hline 5 & Olahraga & Terinfeksi Covid - 19 & $\begin{array}{l}\text { Mencuci tangan sebelum olahraga } \\
\text { dan jaga jarak antara orang yang } \\
\text { olahraga di taman }\end{array}$ \\
\hline 6 & $\begin{array}{l}\text { Petugas kebersihan } \\
\text { membersihkan } \\
\text { taman }\end{array}$ & Terinfeksi Covid - 19 & $\begin{array}{l}\text { Cuci tangan setelah melakukan } \\
\text { bersih - bersih taman, ganti } \\
\text { pakaian serta mandi. }\end{array}$ \\
\hline 7 & $\begin{array}{l}\text { Penggunaan toilet } \\
\text { taman }\end{array}$ & Terinfeksi Covid - 19 & $\begin{array}{l}\text { Menggunaan masker, sering cuci } \\
\text { tangan dan mandi dirumah serta } \\
\text { ganti dengan pakaian yang bersih } \\
\text { ketika sampai rumah }\end{array}$ \\
\hline 8 & $\begin{array}{l}\text { Penggunaan } \\
\text { mushola taman }\end{array}$ & Terinfeksi Covid - 19 & $\begin{array}{l}\text { Menggunaan masker, sering cuci } \\
\text { tangan dan mandi dirumah serta }\end{array}$ \\
\hline
\end{tabular}




\section{Kesimpulan dan Saran}

Identifikasi bahaya dengan menggunakan metode Hazard Identification, Risk Assessment, Risk Control dari 8 kegiatan teridentifikasi 6 kegiatan mempunyai nilai risiko (LR) sedang, 1 kegiatan dengan nilai risiko (LR) tinggi dan 1 kegiatan dengan nilai risiko (LR) ekstrim. Pengendalian risiko yang dilakukan sebaiknya selalu menggunakan masker dan sarung tangan, kemudian membawa cairan pembersih tangan atau hand sanitizer untuk selalu menjaga kebersihan tangan.

\section{Daftar Pustaka}

[1] Tirtoid, "Arti New Normal Indonesia: Tatanan Baru Beradaptasi dengan COVID-19," tirto.id, 2020. [Online]. Available: https://tirto.id/arti-new-normal-indonesia-tatananbaru-beradaptasi-dengan-covid-19-fDB3.

[2] D. K. Chu et al., "Physical distancing, face masks, and eye protection to prevent person-to-person transmission of SARS-CoV-2 and COVID-19: a systematic review and meta-analysis," Lancet, vol. 395, no. 10242, pp. 1973-1987, Jun. 2020.

[3] S. Anand et al., "Prevalence of SARS-CoV-2 antibodies in a large nationwide sample of patients on dialysis in the USA: a cross-sectional study," Lancet, Oct. 2020.

[4] Rahayu Oktavia Asy'ari, "Makalah Bahasa Indonesia Pengertian Covid-19 Dan Bentuk Partisipasi Dalam Memerangi Nya," Res. GATE, no. May, pp. 1-10, 2020.

[5] S. R. B. Waode Azfari Azis, Laode Yusman Muriman, "ANALISIS FAKTOR RISIKO KECELAKAAN KERJA PADA PETANI PENYADAP POHON AREN ATAU ARENGA PINNATA MENGGUNAKAN METODE HAZARD IDENTIFICATION RISK ASSESSMENT AND RISK CONTROL Mhd.," $J$. Penelit. Perawat Prof., vol. 1, no. November, pp. 89-94, 2019.

[6] R. H. Christiva, Rusmiati, and Setiawan, "Analisis Risiko Cemaran Mikrobiologis Pada Pengelolaan Peralatan Makan dan Minum Di Kantin Sekolah Dasar," $J$. Kesehat. Lingkung. Ruwa Jurai, vol. 14, no. 56, pp. 9-18, 2020.

[7] D. Y. Logunov et al., "Safety and immunogenicity of an rAd26 and rAd5 vectorbased heterologous prime-boost COVID-19 vaccine in two formulations: two open, non-randomised phase 1/2 studies from Russia," Lancet, vol. 396, no. 10255, pp. 887-897, Sep. 2020.

[8] P. Pradhan, "A HIRARC MODEL FOR SAFETY AND RISK AT I nternational J ournal of E ngineering $\mathrm{R}$ esearches and $\mathrm{M}$ anagement $\mathrm{S}$ tudies," IJERMS, vol. 3, no. 6, pp. 23-34, 2016.

[9] S. J. Yoon, H. K. Lin, G. Chen, S. Yi, J. Choi, and Z. Rui, "Effect of occupational health and safety management system on work-related accident rate and differences of occupational health and safety management system awareness between managers in South Korea's construction industry," Saf. Health Work, vol. 4, no. 4, pp. 201-209, 2013.

[10] S. Rahayuningsih and J. A. Pradana, "Identifikasi Penerapan Dan Pemahaman 
Kesehatan Dan Keselamatan Kerja Dengan Metode Hazard And Operability Study (Hazop) Pada UMKM Eka Jaya," JATI UNIK J. Ilm. Tek. dan Manaj. Ind., vol. 2, no. 1, p. 20, 2019.

[11] W. Wijaya, S. Rahayuningsih, and A. Komari, "TINGKAT PERILAKU AMAN TENAGA KERJA BAGIAN JAHIT DENGAN MENGGUNAKAN METODE ANTECEDENT BEHAVIOR CONSEQUENCE DI PT. GLOW," JATI UNIK J. Ilm. Tek. dan Manaj. Ind., vol. 1, no. 1, pp. 34-43, 2019.

[12] M. M.Hanafi, "Risiko, Proses Manajemen Risiko, dan Enterprise Risk Management," Manag. Res. Rev., pp. 1-40, 2014.

[13] N. M. Sirait and A. Susanty, "Analisis Risiko Operasional Berdasarkan Pendekatan Enterprise Risk Management ( Erm ) Pada Perusahaan," Ind. Eng. Online J., vol. 5, no. 2012, p. 4, 2016.

[14] A. K. Hua, "Pengenalan Rangkakerja Metodologi dalam Kajian Penyelidikan : Satu Kajian Kes Abstrak Introduction to Metodology Framework in Research Study: A Case Study Abstract Pengenalan,” Malaysian J. Soc. Sci. Humanit., 2016.

[15] Whidmurni, "Penelitian Kuantitatif," Pemaparan Metod. Kuantitatif, 2017.

[16] H. Hasanah, "TEKNIK-TEKNIK OBSERVASI (Sebuah Alternatif Metode Pengumpulan Data Kualitatif Ilmu-ilmu Sosial)," At-Taqaddum, vol. 8, no. 1, p. 21, 2017.

[17] D. S. Purnama, "Analisia Penerapan Metode Hirarc (Hazard Identification Risk Assessment and Risk Control) Dan Hazops (Hazard and Operability Study) Dalam Kegiatan Identifikasi Potensi Bahaya Dan Resiko Pada Proses Unloading Unit Di Pt. Toyota Astra Motor," J. PASTI, vol. IX, no. 3, pp. 311-319, 2017.

[18] K. Sakisaka et al., "Living environment, health status, and perceived lack of social support among people living in temporary housing in Rikuzentakata City, Iwate, Japan, after the Great East Japan Earthquake and tsunami: A cross-sectional study," Int. J. Disaster Risk Reduct., vol. 21, pp. 266-273, 2017.

[19] W. B. M. Ten Brinke, J. Knoop, H. Muilwijk, and W. Ligtvoet, "Social disruption by flooding, a European perspective," Int. J. Disaster Risk Reduct., vol. 21, pp. 312-322, 2017.

[20] I. W. G. E. Triswandana and N. K. Armaeni, "Penilaian Risiko K3 Konstruksi Dengan Metode Hirarc,” vol. 4, no. 1, pp. 2581-2157, 2020.

[21] R. Janius, K. Abdan, and Z. A. Zulkaflli, "Development of a disaster action plan for hospitals in Malaysia pertaining to critical engineering infrastructure risk analysis," Int. J. Disaster Risk Reduct., vol. 21, pp. 168-175, 2017.

[22] R. Alfatiyah, "Analisis Manajemen Risiko Keselamatan dan Kesehatan Kerja dengan Menggunakan Metode HIRARC pada Pekerja Seksi Casting," J. Mesin Teknol. (SINTEK Jurnal), vol. 11, no. 2, pp. 88-101, 2017.

[23] H. Identification, E. T. Force, C. Society, C. S. Copyright, and A. C. Society, Identifying and Evaluating Hazards in Research Laboratories, 1st ed. America: American Chemical Society, 2015.

[24] W. Tambunan, “Analisis Risiko Keselamatan dan Kesehatan Kerja Menggunakan 
Metode Hirarc pada Proses Perbaikan Kapal Tugboat (Studi Kasus PT Marga Surya Shipindo, Samarinda)," J. Ind. Manuf. Eng., vol. 3, no. 1, p. 33, 2019.

[25] A. Primasari, H. Denny, and E. Ekawati, "Penerapan Hazard Identification Risk Assessment and Risk Control (Hirarc) Sebagai Pengendalian Potensi Kecelakaan Kerja Di Bagian Produksi Body Bus Pt. X Magelang," J. Kesehat. Masy., vol. 4, no. 1, pp. 284-292, 2016.

[26] A. Kurniawan, M. Santoso, and M. R. Dhani, "Identifikasi Bahaya pada Pekerjaan Maintenance Kapal Menggunakan Metode HIRARC dan FTA Dengan Pendekatan Fuzzy di Industri Kapal,” Kesehat. dan Keselam. Kerja, no. 2581, pp. 182-186, 2017.

[27] T. Ihsan, B. V. Mayolan, S. M. Yardi, and T. Edwin, “Analisis penerapan recordable incident rate dalam sistem manajemen kesehatan dan keselamatan kerja di pt semen padang," J. Kesehat. Masy. Andala, pp. 3-9, 2019. 